\title{
Measuring relative telomere length: Is tissue an issue?
}

\author{
Monica M. Gramatges and Alison A. Bertuch \\ Department of Pediatrics, Baylor College of Medicine, BCM320, Houston, TX 77030, USA
}

Commentary on: Shahinaz Gadalla et al. Telomere Length in Blood, Buccal Cells, and Fibroblasts from Patients with Inherited Bone Marrow Failure Syndrome. Aging. 2010; 2: this issue.

Corresponding author: Alison A. Bertuch, MD/PhD; E-mail: abertuch@txccc.org

Received: 11/19/10; Accepted: 11/19/10; Published: 11/23/10

Copyright: (C) Gramatges et al. This is an open-access article distributed under the terms of the Creative Commons Attribution License, which permits unrestricted use, distribution, and reproduction in any medium, provided the original author and source are credited

Telomeres, the specialized structures at chromosome ends, consist of long stretches of protein-bound TTAGGG repeats [1]. In certain cell types, such as germ cells and stem cell populations, the length of telomeric DNA is maintained by the enzyme telomerase. Most somatic cells, however, lack sufficient telomerase; consequently, telomeric DNA shortens progressively with each cell division. Upon reaching a critically short length, proliferation is halted and cells often enter a state of senescence. Thus, progressive telomere shortening is thought to serve as a molecular clock for cellular replicative aging. Based upon this fundamental tenet of telomere biology, an everincreasing number of studies spanning a wide spectrum of human conditions have utilized telomere length, typically measured in buccal cells or blood mononuclear cells, as a biomarker for cellular replicative age. Individuals with relatively short age-adjusted telomere lengths, due to a combination of inherent factors and environmental stressors, are considered to have accelerated cellular replicative aging, potentially resulting in increased disease susceptibility [2].

Telomere length is also used as a diagnostic tool in diseases characterized by fundamental derangements of telomere biology, such as dyskeratosis congenita (DC). $\mathrm{DC}$ is a rare genetic disorder stemming from a defect in telomere maintenance. This defect results in a broad and highly variable clinical phenotype consisting of predisposition to bone marrow failure and malignancy, a triad of mucocutaneous features, and a number of less frequent manifestations such as pulmonary fibrosis and liver disease [3]. In nearly all reported cases, affectted individuals have severely shortened telomeres, which can be directly attributed to mutations in genes encoding components of telomerase or a telomere-associated protein in approximately half of cases.

Hence, DC is considered the prototype of a heritable disorder of telomere maintenance. In DC, very short telomeres are observed across different classes of peripheral white blood cells, affecting both lymphoid subpopulations and granulocytes [4]. In contrast, in other inherited bone marrow failure syndromes (IBMFS), telomere length shortening is less pronounced and the effect is largely restricted to granulocytes. Rather than being due to an inherent defect in telomere maintenance, the short telomeres in granulocytes in these cases are thought to reflect accelerated progenitor/stem cell turnover secondary to bone marrow stress.

The utility of telomere length both as a biomarker for accelerated cellular replicative aging and as a diagnostic marker for a constitutional defect in telomere maintenance solicits a question as to how telomere length varies in different tissues in conditions associated with accelerated cellular aging as compared to disorders where telomere length maintenance is compromised. In this issue of Aging, Gadalla, et al, begin to address this question by simultaneously examining relative telomere length in granulocytes, fibroblasts and buccal cells within individuals affected by DC and other IBMFS [5]. Although the number of subjects was small, strong correlations between blood, buccal cells, and fibroblasts were observed in the study population as a whole. When taken individually, however, only cells from subjects with DC demonstrated significant correlation. Telomere shortening in different cell types has been described previously in DC $[4,6,7]$, however, the 
striking degree of correlation observed in the individual subjects examined in this study demonstrates the global defect in telomere maintenance in this disorder. Notably, relative telomere length was longer in fibroblasts and buccal cells when compared to granulocytes across each specific IBMFS, perhaps reflecting the replicative histories of these cell types. Though significant intra-individual telomere length correlation between disparate tissue types has been observed in healthy subjects [8-13], few studies involving subjects with disease have evaluated telomere length in multiple tissues. By demonstrating such correlations within the DC population, Gadalla et al. provide evidence to support the use of relative telomere length in readily accessible cells such buccal or blood as a surrogate for inherent telomere maintenance capacity.

A higher proportion of single nucleotide variants within specific telomerase-associated genes, such as TERT and $T E R C$, which encode the catalytic and RNA subunits of telomerase, respectively, have been described in cases with disease compared with a control population [14-19]. Interestingly, some variants have been described in familial cohorts with a predominant single phenotype, such as non-alcoholic liver disease or idiopathic pulmonary fibrosis, whereas the broader spectrum of the DC-associated phenotypes is not observed [16,20,21]. The impact of many of these variants on telomere maintenance has been inferred by measuring telomerase activity following transfection of the variant alleles into TERT or TERC-deficient cell lines, and by measuring telomere length, most often in leukocytes. Examining multiple tissue types in these cases of isolated phenotypes, similar to the approach of Gadalla, et al, may lend further support to the underlying impact of these telomerase gene variants on constitutional telomere length maintenance.

\section{REFERENCES}

1. Blasco MA. Telomeres and human disease: ageing, cancer and beyond. Nat Rev Genet. 2005; 6: 611-622.

2. Gilley D, Herbert BS, Huda N, Tanaka H, Reed T. Factors impacting human telomere homeostasis and age-related disease. Mech Ageing Dev. 2008; 129: 27-34.

3. Walne AJ and Dokal I. Advances in the understanding of dyskeratosis congenita. Br J Haematol. 2009; 145: 164-172.

4. Alter BP, Baerlocher GM, Savage SA, Chanock SJ, Weksler BB, Willner JP, Peters JA, Giri N, Lansdorp PM. Very short telomere length by flow fluorescence in situ hybridization identifies patients with dyskeratosis congenita. Blood. 2007; 110: 1439-1447.

5. Gadalla SM, Cawthon R, Giri N, Alter BP, Savage SA. Telomere Length in Blood, Buccal Cells, and Fibroblasts from Patients with Inherited Bone Marrow Failure Syndromes. Aging. 2010; 2: this issue.

6. Gourronc FA, Robertson M, Herrig AK, Lansdorp PM, Goldman FD, Klingelhutz AJ. Proliferative defects in dyskeratosis congenita skin keratinocytes are corrected by expression of the telomer-ase reverse transcriptase, TERT, or by activation of endogenous telomerase through expression of papillomavirus E6/E7 or the telomerase RNA component, TERC. Exp Dermatol. 2010; 19: 279-288.

7. Westin ER, Chavez E, Lee KM, Gourronc FA, Riley S, Lansdorp PM, Goldman FD, Klingelhutz AJ. Telomere restoration and extension of proliferative lifespan in dyskeratosis congenita fibroblasts. Aging Cell. 2007; 6: 383-394.

8. Friedrich $U$, Griese $E$, Schwab $M$, Fritz $P$, Thon $K$, Klotz U. Telomere length in different tissues of elderly patients. Mech Ageing Dev. 2000; 119: 89-99.

9. Chang $E$, Harley $C B$. Telomere length and replicative aging in human vascular tissues. Proc Natl Acad Sci USA. 1995; 92: 11190-11194.

10. Mondello C, Petropoulou C, Monti D, Gonos ES, Franceschi C, Nuzzo F. Telomere length in fibroblasts and blood cells from healthy centenarians. Exp Cell Res. 1999; 248: 234-242.

11. Butler MG, Tilburt J, DeVries A, Muralidhar B, Aue G, Hedges $\mathrm{L}$, Atkinson J, Schwartz H. Comparison of chromosome telomere integrity in multiple tissues from subjects at different ages. Cancer Genet Cytogenet. 1998; 105: 138-144.

12. Thibeault SL, Glade RS, Li W. Comparison of telomere length of vocal folds with different tissues: a physiological measurement of vocal senescence. J Voice. 2006; 20: 165-170.

13. Weng NP, Levine $B L$, June $C H$, Hodes RJ. Human naive and memory $T$ lymphocytes differ in telomeric length and replicative potential. Proc Natl Acad Sci U S A. 1995; 92: 11091-11094.

14. Yamaguchi H, Baerlocher GM, Lansdorp PM, Chanock SJ, Nunez $O$, Sloand $E$, Young NS. Mutations of the human telomerase RNA gene (TERC) in aplastic anemia and myelodysplastic syndrome. Blood. 2003; 102: 916-918.

15. Diaz de Leon A, Cronkhite JT, Katzenstein AL, Godwin JD, Raghu G, Glazer CS, Rosenblatt RL, Girod CE, Garrity ER, Xing C, Garcia CK. Telomere lengths, pulmonary fibrosis and telomerase (TERT) mutations. PLoS One. 2010; 5: e10680.

16. Calado RT, Regal JA, Kleiner DE, Schrump DS, Peterson NR, Pons V, Chanock SJ, Lansdorp PM, Young NS. A spectrum of severe familial liver disorders associate with telomerase mutations. PLoS One. 2009; 4: e7926.

17. Hills $M$, Lansdorp PM. Short telomeres resulting from heritable mutations in the telomerase reverse transcriptase gene predispose for a variety of malignancies. Ann N Y Acad Sci. 2009; 1176: 178-190.

18. Yamaguchi H, Calado RT, Ly H, Kajigaya S, Baerlocher GM, Chanock SJ, Lansdorp PM, Young NS. Mutations in TERT, the gene for telomerase reverse transcriptase, in aplastic anemia. N Engl J Med. 2005; 352: 1413-1424.

19. Calado RT, Regal JA, Hills M, Yewdell WT, Dalmazzo LF, Zago MA, Lansdorp PM, Hogge D, Chanock SJ, Estey EH, Falcao RP, Young NS. Constitutional hypomorphic telomerase mutations in patients with acute myeloid leukemia. Proc Natl Acad Sci USA. 2009; 106: 1187-1192.

20. Cronkhite JT, Xing C, Raghu G, Chin KM, Torres F, Rosenblatt $\mathrm{RL}$, Garcia CK. Telomere shortening in familial and sporadic pulmonary fibrosis. Am J Respir Crit Care Med. 2008; 178: 729-737. 